Agro-Science Journal of Tropical Agriculture, Food, Environment and Extension Volume 11 Number 3 September $2012 \quad 12$ - 19

ISSN III9-7455

\title{
RESPONSE OF SHAVER BROWN HENS TO FEEDS OF DIFFERENT SOURCES IN THE HUMID TROPICAL ENVIRONMENT
}

\author{
Ani, A. O and Oyeagu, C. E \\ Department of Animal Science, University of Nigeria, Nsukka, Nigeria \\ Corresponding author: Email:austinani2011@yahoo.com
}

\begin{abstract}
A twelve-week study was conducted to determine the effect of feed type on performance of Shaver brown hens in the humid tropical environment. One hundred and twenty (120) Shaverbrown hens of 28 weeks of age were used for the study. The hens were divided into five groups of 24 hens each and each group was randomly assigned to one of five experimental diets (self-compounded layers' diet (B), and four commercial layers' diets-A (reference diet), $C$, $D$, and $E$, respectively).Each diet constituted a treatment and each treatment was replicated thrice with 8 birds per replicate. Each hen in each replicate received about $130 \mathrm{~g}$ of layers' mash daily and ad libitum supply of water for twelve weeks. Eggs were collected daily and recorded for each hen. Results show that birds fed diet E had significantly $(P<0.05)$ lower average daily feed intake $(A D F I)$ value than those fed diet $B$, and commercial diets $A, C$ and $D$, which had similar ADFI values $(P>0.05)$. Birds fed diet $B$ had significantly $(P<0.05)$ less egg weight than hens fed commercial diet $D$. Birds fed diets $B$ to $E$ had similar shell thickness values $(P>0.05)$ and these were higher $(P<0.05)$ than the shell thickness value of hens that consumed diet A. Birds fed commercial diet $D$ had significantly $(P<0.05)$ higher yolk height and yolk index than those fed diet B. The dozens of eggs produced per bird, revenue from dozens of eggs produced and gross profit were not significantly $(P>0.05)$ affected by dietary treatments. It was concluded that since none of the five diets used in feeding the Shaver brown hens was superior to the other, farmers may therefore use any of them to feed laying birds.
\end{abstract}

Keywords: Feed type, egg production, egg quality, Shaver brown hens, tropical environment

\section{INTRODUCTION}

One of the major hindrances to commercial egg production is the poor quality of feed for layers. Afolayan et al. (2009) states that the type of feed used in feeding birds play an important role in the performance of the laying hen. This shows that the availability of a nutritionally balanced feed is very important in poultry production. Most poultry farmers are ignorant about the nutrient requirements of poultry and how feed ingredients can be manipulated to satisfy these requirements. As a result of ignorance, farmers rely on any commercial feed in the locality (Lorgyer et al., 2007). In Nigeria for instance, feed producers often market feeds whose chemical compositions differ markedly from the label content. The problems associated with analyzing these feeds to find out their true chemical composition are numerous, which include lack of facilities, cost involvement and distance. This has resulted in many farmers sustaining heavy losses from feeding substandard rations to poultry due to delay in the attainment of market weight and prolonged feeding of layers before the first set of eggs are laid (Asaniyan and Laseinde, 2005). Many a time, commercial feeds are very expensive. Payne and Wilson (1999) have also shown that the poor development of commercial egg production could be attributed to inadequate and high cost of feed which is not readily available. Atteh (2002), Adebayo et al. (2002) and Kehinde (2006) report that feed alone accounts for over seventy percent of total cost of producing broilers and eggs. Farmers may not have a direct influence on the feed cost when feed is purchased from commercial feed millers. Therefore, many farmers change from one commercial feed to another in search of a better feed while a good number have decided to produce their own feeds. As a matter of fact, feed costs as well as the quality of the feeds are 
among the factors which dictate farmer's preference for commercial or self-compounded feeds (Adebayo et al., 2002; Umeh and Odo, 2002). Many farmers also believe that self-made feeds are cheaper than commercial feeds (Adesehinwa et al., 1996; Adebayo et al., 2002). However, it is necessary that before a standard diet for poultry can be formulated, adequate knowledge of the nutrient requirement and the nutrient composition of the different ingredients among others must be known to ascertain their potencies (Idahor et al. 2010). The present study was therefore conducted to investigate the effect of feed type on performance of Shaver brown hens and it's cost implications in the humid tropical environment

\section{MATERIALS AND METHOD}

The study was conducted at the Poultry Unit of the Department of Animal Science Teaching and Research Farm, University of Nigeria, Nsukka. Nsukka lies within longitude $6^{\circ} 45^{1} \mathrm{E}$ and $7^{\circ} \mathrm{E}$ and latitude $7^{\circ}$ $12.5^{1} \mathrm{~N}$ (Offomata 1975) and at an altitude of $447 \mathrm{~m}$ above sea level. The climate is typically tropical, with relative humidity ranging from $65-80 \%$ and mean daily temperature of $26.8^{\circ} \mathrm{C}$ (Agbagha, et al 2000). The rainy season is between April - October and dry season between November - March with annual rainfall range of $1680-1700 \mathrm{~mm}$ (Breinholt et al., 1981). The entire study lasted for 12 weeks.

\section{Experimental Diets}

Five experimental diets (A, B, C, D and E) were used as follows: diets A, C, D and E comprised Top ${ }^{\circledR}$, Gold medal $^{\circledR}$, Chidera ${ }^{\circledR}$ and Vital $^{\circledR}$ commercial layers feeds, respectively while $\operatorname{diet} B$ was selfcompounded (homemade) layers' mash. The percentage composition of the self -compounded diet is presented in Table 1.

\section{Animals and management}

The experiment was carried out in accordance with the provisions of the Ethical Committee on the use of animals and humans for biomedical research of the University of Nigeria, Nsukka (2006). A total of one hundred and twenty (120) 28 week-old Shaver brown hens were used for the study. The hens were housed in the laying house situated at the Poultry Unit of the Department of Animal Science Teaching and Research Farm, University of Nigeria, Nsukka. The house is an open - sided tropical type, fitted with two-tier battery cages with feeders and drinkers. Flat aluminum metal plates were constructed and used to partition the feeding troughs at intervals of four (4) cages. The idea was to prevent spillover of feeds from or to neighboring treatments. The birds were randomly divided into five groups of 24 hens each. Each group was randomly assigned to one of the five diets (A, B,
C, D and E, respectively) using a completely randomized design (CRD).

Diet A which has been successfully established in the feed market for a long time served as the control diet. Each diet constituted a treatment. Each treatment was replicated three (3) times with eight (8) birds per replicate. Two hens were housed in a cage measuring 49 x 35 x $42 \mathrm{~cm}$. Four (4) of such cages constituted a replicate. Each hen in a replicate received about $130 \mathrm{~g}$ of layers' mash daily and ad libitum supply of water for the 12 week experimental period. As a general flock prophylactic management strategy, routine vaccinations were administered as and when due.

\section{Performance Parameters Measured}

The parameters measured included:

Initial and final body weights: These were measured at the beginning and at the end of the experiment, respectively.

Average body weight $(\mathrm{kg})=$ Final body weight - initial body weight.

Average daily feed intake $(\mathrm{g})$ :

Feed Offered $(g)$ - Feed Refusals $(g)$ Number of Hens

Feed conversion ratio

Quantity of feed consumed

Doz. of eggs produced

(Jabben et al., 2004).

Average Egg Weight (g) $=$

Total weight of eggs $(\mathrm{g})$ per treatment

Total number of birds in that treatment

Percentage egg production: Percentage egg production was calculated using the formula as shown below:

Hen day Production (\%)

$$
\frac{\text { Average No of eggs per day }}{\text { No of birds alive }} \times 100 \%
$$

Egg weight (g): Egg weight was taken for every egg collected for the hens and the weighing was done for all the collected eggs within one hour of collection. Electronic balance (D \& G sensitive scale) was used and the measurement expressed in grammes.

Egg quality: Sixteen (16) eggs were randomly selected weekly for egg quality analysis. The indices determined were as follows:

Egg shell weight (g): Each egg was carefully broken and dried after which the egg was weighed using a weighing balance.

Egg shell thickness ( $\mathrm{mm})$ : This was determined by pulling off the shell immediately the egg was broken and the shell was air-dried for a day ( 24 hours) after which the egg shell thickness was determined with the help of a micrometer screw guage. 
Egg shape index: The egg shape index was calculated as the proportion of egg length to diameter.

Albumin height and diameter $(\mathrm{mm} / \mathrm{cm})$ : The eggs after weighing were broken into a flat bottom glass (beaker) positioned on a flat surface. The albumin height was measured using a tripod micrometer. Albumin diameter was taken as the maximum cross sectional diameter of the albumin using a pair of calipers and read on a ruler calibrated in millimeter.

Yolk height and diameter $(\mathrm{mm} / \mathrm{cm})$ : The eggs after weighing were broken into a flat bottom glass (beaker) positioned on a flat surface. The yolk height was measured using a tripod micrometer. Yolk diameter was taken as the maximum cross sectional diameter of the yolk using a pair of calipers and read on a ruler calibrated in millimeter.

Albumin index: The albumin index was calculated as the proportion of yolk height to diameter.

Yolk Index: The yolk index was calculated as the proportion of yolk height to diameter.

Haugh unit: This was calculated from the values obtained from the albumin height and egg weight by using the formula: Haugh's unit $=100 \log (\mathrm{H}+7.57$ $\left.1.7 \mathrm{~W}^{0.37}\right)$ as described by Williams (1992).

\section{Determination of Cost Implication Indices}

Data generated were used to determine the cost implication of feeding self-compounded layers' diet and some commercial layers' diets to the experimental hens. The economic indices determined included the following:

Dozens of Egg Produced per bird (dozen) = Total egg number per bird

\section{2}

Price per crate of egg ( ): A crate of egg was sold at N650 as at the time of the research work.

Cost of $1 \mathrm{~kg}$ of feed $(\aleph)$
$\frac{\text { Amount per bag of feed }(N)}{25 \mathrm{~kg} \text { feed }(1 \text { bag of feed })}$
$\frac{\text { Total feed consumed feed consumed }(\mathrm{g})}{1000}$

Cost of Feed Consumed $(\mathbb{N})=$ Total feed consumed $(\#) \times$ Cost of $\mathrm{kg}$ of feed $(\$)$

Price of a dozen of Egg ( $)=1$ dozen of egg was sold at $\$ 260.40$ as at the time of the research work.

Revenue from dozens of Egg Produced $(\#)=$ Total dozens of egg produced $x$ Price of one dozen of egg.

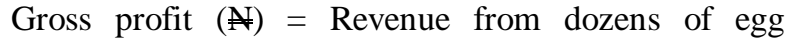
produced ( $)$ - Cost of feed Consumed ( $\$$ ) (all other things been equal).

\section{Proximate and Statistical Analyses}

Samples of the five experimental diets were analyzed for their proximate compositions according to AOAC (2006) methods. Data collected were subjected to analysis of variance (ANOVA) in a completely randomized design as outlined by Steel and Torrie (1980) using Statistical Package for the Social Sciences (SPSS, 2003), windows version 8.0. Significantly different means were separated using Duncan's new multiple range test (Duncan, 1955) option in SPSS (2003).

\section{RESULTS AND DISCUSSION}

Effect of Feed Type on Laying Performance of Shaver Brown Hens

Data on performance of Shaver Brown hens fed selfcompounded layers' diet (B) and four different commercial layers' diets (A, C, D and E) are presented in Table 3. Average daily feed intake and feed conversion ratio were significantly $(\mathrm{P}<0.05)$ affected by treatments. Birds fed diet $\mathrm{E}$ had significantly $\mathrm{P}<0.05)$ lower average daily feed intake value than those fed diet B (Self-compounded), commercial diets A (reference diet), $\mathrm{C}$ and $\mathrm{D}$, which had similar ADFI values $(\mathrm{P}>0.05)$. Hens fed diet $\mathrm{D}$ had similar $(\mathrm{P}>0.05)$ FCR value with those fed $\operatorname{diet} A$, and this was significantly $\mathrm{P}<0.05)$ higher than the FCR values of birds fed diet B (self-compounded), $\mathrm{C}$ and $\mathrm{E}$. The FCR values of birds fed diets $\mathrm{A}, \mathrm{B}, \mathrm{C}$ and $\mathrm{E}$ were similar $(\mathrm{P}>0.05)$. Although significant differences existed between treatments in ADFI and FCR, all the birds subjected to the different dietary treatments had comparable performance in terms of hen day production $\%$, body weight gain and final body weight. However, the low feed intake and high efficiency of feed utilization observed in treatment $\mathrm{E}$ (commercial feed $\mathrm{E}$ ) is of great advantage since it may likely result in reduced cost of production. It does seem therefore that birds exposed to commercial diet $\mathrm{E}$ had the ability to convert significantly low amount of feed into egg. It could also be that the energy contained in the feed consumed by birds exposed to diet $\mathrm{E}$ was high enough to satisfy their dietary energy needs. Earlier Atteh, (2004) had shown that variation in feed intake values was related to the energy content of the diets. Birds like other animals eat to satisfy their energy requirements (Jurgens, 2002; Macdonald et al., 2002). Could it be that diet $\mathrm{E}$ had some performance enhancers for which information was not provided by the producers? This reasoning becomes necessary because the current trend in feed producion involves the use of bio-acids, enzymes, coccidiostats, toxin binders, antioxidants, etc. that are known to enhance nutrient utilization, and therefore promote better performance by birds (Abeke et al., 200 8). 
Table 1: Percentage and calculated compositions of experimental diets

\begin{tabular}{|c|c|c|c|c|c|}
\hline \multirow[t]{2}{*}{ Ingredients } & \multicolumn{3}{|c|}{ Diets } & \multirow[b]{2}{*}{$\mathrm{D}$} & \multirow[b]{2}{*}{$\mathrm{E}$} \\
\hline & $\mathrm{A}$ & $\mathrm{B}$ & $\mathrm{C}$ & & \\
\hline Maize & - & 48 & - & - & - \\
\hline Wheat offal & - & 10 & - & - & - \\
\hline Palm kernel cake & - & 14 & - & - & - \\
\hline Groundnut cake & - & 10 & - & - & - \\
\hline Fish meal & - & 2 & - & - & - \\
\hline Soy bean meal & - & 6 & - & - & - \\
\hline Bone meal & - & 3 & - & - & - \\
\hline Lime stone & & 6 & & & \\
\hline Salt & - & 0.25 & - & - & - \\
\hline Lysine & - & 0.25 & - & - & - \\
\hline Methionine & - & 0.25 & - & - & - \\
\hline Layers' premix* & - & 0.25 & - & - & - \\
\hline Total & & 100 & & & \\
\hline \multicolumn{6}{|l|}{ Calculated composition: } \\
\hline Crude protein $(\%)$ & 16.50 & 17.00 & 16.50 & 16.50 & 16.50 \\
\hline Crude fibre (\%) & 6.00 & 5.49 & 6.50 & 6.00 & 6.50 \\
\hline Ether extract (\%) & 5.00 & 4.97 & 4.50 & 4.56 & 4.00 \\
\hline Lysine $(\%)$ & 0.80 & 1.24 & 1.00 & 0.90 & 1.00 \\
\hline Methionine (\%) & 0.34 & 0.92 & 0.50 & 0.45 & 0.55 \\
\hline Calcium (\%) & 3.80 & 3.73 & 3.50 & 3.55 & 3.60 \\
\hline Energy (Mcal/kg ME) & 2500 & 2700 & 2550 & 2600 & 2650 \\
\hline
\end{tabular}

Table 2: Proximate compositions of the experimental diets.

\begin{tabular}{llllll}
\hline Determined Compositions & Diets & & & & D \\
\hline Dry matter (\%) & A & B & C & D \\
Crude Protein (\%) & 88.55 & 88.65 & 88.70 & 89.09 & 88.70 \\
Crude fibre (\%) & 17.30 & 17.80 & 17.00 & 17.20 & 16.96 \\
Ether extract (\%) & 4.60 & 3.00 & 4.45 & 4.15 & 5.00 \\
Ash (\%) & 5.33 & 5.77 & 5.17 & 5.56 & 5.64 \\
Nitrogen-free extract (\%) & 10.70 & 11.40 & 10.40 & 13.30 & 13.10 \\
\hline
\end{tabular}

\section{Effect of Feed Type on External Egg Parameters of Shaver Brown Hen}

The effect of feed type on external egg characteristics of Shaver brown hens fed self-compounded and four commercial diets are shown in Table 4. Average egg weight and egg shell thickness were significantly $(\mathrm{P}<0.05)$ influenced by treatments, while no significant $(\mathrm{P}>0.05)$ difference existed among treatments in egg shell weight, egg diameter, egg length and egg shape index. Birds fed self-compounded diet (B) had significantly $(\mathrm{P}<0.05)$ less egg weight than hens fed commercial diet D. Hens fed all the commercial diets had similar egg weight values, while hens fed diet B (self-compounded)had similar egg weight values with those fed commercial diets $\mathrm{A}, \mathrm{C}$ and $\mathrm{E}(\mathrm{P}>0.05)$.
Birds fed diets $\mathrm{B}$ to $\mathrm{E}$ had similar shell thickness values $(\mathrm{P}>0.05)$ and these were higher $(\mathrm{P}<0.05)$ than the shell thickness value of hens that consumed diet $\mathrm{A}$. The fact that hens fedself-compounded diet had less egg weight and high shell thickness, tends to suggest that larger eggs have thinner shells and vice versa. This is in accordance with earlier reports (Singh, 1990; Olayeni et al., 2007; Agaviezor et al., 2008). The values for egg shell thickness obtained in this study ranged from $0.23 \mathrm{~mm}-0.26 \mathrm{~mm}$ and are at variance with the range of values $(0.30 \mathrm{~mm}$ to $0.36 \mathrm{~mm})$ reported by Oluyemi and Roberts (2000). The variation could have been as a result of differences in feed and strain of birds. 
Table 3: Effect of feed type on laying performance of shaver brown hens

\begin{tabular}{|c|c|c|c|c|c|c|}
\hline Parameters & $\begin{array}{l}\text { Commercial diet } \\
\text { A (control) }\end{array}$ & $\begin{array}{l}\text { Homemade diet } \\
\text { B }\end{array}$ & $\begin{array}{l}\text { Commercial diet } \\
\text { C }\end{array}$ & $\begin{array}{l}\text { Commercial diet } \\
\text { D }\end{array}$ & $\begin{array}{l}\text { Commercial diet } \\
\text { E }\end{array}$ & Sig. \\
\hline $\begin{array}{l}\text { Initial weight } \\
(\mathrm{kg})\end{array}$ & $1.31 \pm 0.07$ & $1.26 \pm 0.07$ & $1.26 \pm 0.08$ & $1.40 \pm 0.06$ & $1.28 \pm 0.04$ & $\mathrm{NS}$ \\
\hline $\begin{array}{l}\text { Final weight } \\
(\mathrm{kg})\end{array}$ & $1.37 \pm 0.05$ & $1.38 \pm 0.06$ & $1.33 \pm 0.08$ & $1.47 \pm 0.08$ & $1.35 \pm 0.09$ & NS \\
\hline $\begin{array}{l}\text { Av body wt gain } \\
(\mathrm{kg})\end{array}$ & $0.06 \pm 0.04$ & $0.18 \pm 0.05$ & $0.07 \pm 0.04$ & $0.07 \pm 0.03$ & $0.07 \pm 0.05$ & NS \\
\hline $\begin{array}{l}\text { Hen day } \\
\text { production }(\%)\end{array}$ & $75.00 \pm 5.00$ & $65.67 \pm 1.33$ & $78.33 \pm 2.60$ & $63.67 \pm 3.26$ & $59.67 \pm 4.66$ & NS \\
\hline $\begin{array}{l}\text { Av daily feed } \\
\text { intake }(\mathrm{g})\end{array}$ & $76.67 \pm 3.97^{\mathrm{a}}$ & $75.42 \pm 3.70^{\mathrm{a}}$ & $80.83 \pm 0.83^{\mathrm{a}}$ & $84.17 \pm 5.31^{\mathrm{a}}$ & $58.75 \pm 2.17^{b}$ & $*$ \\
\hline $\begin{array}{l}\text { Feed conversion } \\
\text { ratio }\end{array}$ & $1.41 \pm 0.08^{\mathrm{ab}}$ & $1.38 \pm 0.10^{\mathrm{b}}$ & $1.25 \pm 0.03^{b}$ & $1.60 \pm 0.17^{\mathrm{a}}$ & $1.20 \pm 0.09^{b}$ & $*$ \\
\hline
\end{tabular}

Table 4: Effect of feed type on external egg parameters of Shaver brown hens

\begin{tabular}{|c|c|c|c|c|c|c|}
\hline Parameters & $\begin{array}{l}\text { Commercial diet } \\
\text { A (control) }\end{array}$ & $\begin{array}{l}\text { Homemade diet } \\
\text { B }\end{array}$ & $\begin{array}{l}\text { Commercial diet } \\
\text { C }\end{array}$ & $\begin{array}{l}\text { Commercial diet } \\
\text { D }\end{array}$ & $\begin{array}{l}\text { Commercial diet } \\
\text { E }\end{array}$ & Sig \\
\hline Av egg wt(g) & $65.11 \pm 0.99^{\mathrm{ab}}$ & $62.16 \pm 1.08^{\mathrm{b}}$ & $64.56 \pm 1.33^{\mathrm{ab}}$ & $67.30 \pm 1.33^{\mathrm{a}}$ & $65.40 \pm 1.94^{\mathrm{ab}}$ & $*$ \\
\hline $\begin{array}{l}\text { Egg shell } \\
\text { thickness(mm) }\end{array}$ & $0.23 \pm 0.01^{\mathrm{b}}$ & $0.26 \pm 0.01^{\mathrm{a}}$ & $0.25 \pm 0.01^{\mathrm{a}}$ & $0.25 \pm 0.01^{\mathrm{a}}$ & $0.26 \pm 0.01^{\mathrm{a}}$ & $*$ \\
\hline Egg shell weight (g) & $8.05 \pm 0.02$ & $7.84 \pm 0.64$ & $8.43 \pm 0.11$ & $8.89 \pm 0.17$ & $8.68 \pm 0.43$ & NS \\
\hline Egg diameter $(\mathrm{cm})$ & $3.31 \pm 0.01$ & $3.29 \pm 0.02$ & $3.30 \pm 0.04$ & $3.34 \pm 0.07$ & $3.35 \pm 0.04$ & NS \\
\hline Egg length $(\mathrm{cm})$ & $4.69 \pm 0.04$ & $4.50 \pm 0.02$ & $4.65 \pm 0.07$ & $4.74 \pm 0.04$ & $4.66 \pm 0.07$ & NS \\
\hline Egg shape index & $1.42 \pm 0.02$ & $1.37 \pm 0.64$ & $1.41 \pm 0.11$ & $1.42 \pm 0.17$ & $1.39 \pm 0.43$ & NS \\
\hline
\end{tabular}

\section{Effect of feed type on Internal Egg Parameters of Shaver Brown Hen}

Table 5 showed the internal egg characteristics of Shaver brown hens to selfcompounded and four commercial diets. Haugh unit score, yolk weight, yolk diameter, albumin weight, albumin height, albumin diameter, albumin length and albumin index were not significantly $(\mathrm{P}>0.05)$ influenced by dietary treatments while yolk height and yolk index were significantly $(\mathrm{P}<0.05)$ affected by treatments. Birds fed commercial diet $\mathrm{D}$ had significantly $(\mathrm{P}<0.05)$ higher yolk height and yolk index than those fed self-compoundeddiet (B). Birds fed diet B had similar yolk height and yolk index with those fed commercial diets $\mathrm{A}, \mathrm{C}$ and $\mathrm{E}(\mathrm{P}>0.05)$, while birds fed the commercial diets also had similar yolk height and yolk index $(\mathrm{P}>0.05)$. The significant $(\mathrm{P}<0.05)$ difference which existed among treatments in yolk index is not in line with earlier report (Abeke et al., 2008) which showed that no significant $(\mathrm{P}>0.05)$ differences existed between dietary treatments in yolk index. It has been shown that high yolk index value is one of the indicators of internal egg quality (Dudusola, 2010). It does seem therefore that birds which consumed commercial feed D produced eggs whose internal egg quality was superior to the ones produced by birds that consumed diet B (self-compounded). 
Table 5: Effect of feed type on internal egg parameters of Shaver brown hens

\begin{tabular}{|c|c|c|c|c|c|c|}
\hline Parameters & $\begin{array}{l}\text { Commercial diet } \\
\text { A (control) }\end{array}$ & Homemade diet B & $\begin{array}{l}\text { Commercial diet } \\
\text { C }\end{array}$ & $\begin{array}{l}\text { Commercial diet } \\
\text { D }\end{array}$ & $\begin{array}{l}\text { Commercial diet } \\
\text { E }\end{array}$ & Sig. \\
\hline Haugh unit score (\%) & $88.33 \pm 0.88$ & $87.33 \pm 2.40$ & $88.33 \pm 6.03$ & $89.67 \pm 2.67$ & $89.00 \pm 1.00$ & NS \\
\hline Yolk wt (g) & $15.95 \pm 0.51$ & $15.35 \pm 0.08$ & $15.88 \pm 0.16$ & $16.04 \pm 0.56$ & $15.55 \pm 0.62$ & NS \\
\hline Yolk height (mm) & $18.55 \pm 0.15^{\mathrm{ab}}$ & $17.47 \pm 0.71^{\mathrm{b}}$ & $18.29 \pm 0.19^{\mathrm{ab}}$ & $18.80 \pm 0.37^{\mathrm{a}}$ & $18.04 \pm 0.21^{\mathrm{ab}}$ & $*$ \\
\hline Yolk diameter $(\mathrm{cm})$ & $3.00 \pm 0.07$ & $3.04 \pm 0.02$ & $2.30 \pm 0.03$ & $3.00 \pm 0.04$ & $3.00 \pm 0.05$ & NS \\
\hline Yolk index & $0.62 \pm 0.01^{\mathrm{ab}}$ & $0.57 \pm 0.03^{\mathrm{b}}$ & $0.61 \pm 0.01^{\mathrm{ab}}$ & $0.63 \pm 0.01^{\mathrm{a}}$ & $0.60 \pm 0.01^{\mathrm{ab}}$ & $*$ \\
\hline Albumin wt (g) & $38.72 \pm 0.07$ & $36.48 \pm 0.29$ & $37.57 \pm 1.02$ & $40.00 \pm 1.77$ & $39.68 \pm 1.02$ & NS \\
\hline Albumin height (mm) & $8.08 \pm 0.16$ & $7.77 \pm 0.45$ & $8.07 \pm 0.56$ & $8.45 \pm 0.54$ & $8.14 \pm 0.12$ & NS \\
\hline Albumin diameter $(\mathrm{cm})$ & $6.24 \pm 0.10$ & $6.06 \pm 0.10$ & $6.04 \pm 0.19$ & $6.29 \pm 0.21$ & $6.33 \pm 0.25$ & NS \\
\hline Albumin length $(\mathrm{cm})$ & $7.74 \pm 0.25$ & $7.78 \pm 0.46$ & $7.60 \pm 0.07$ & $8.32 \pm 0.43$ & $7.63 \pm 0.48$ & NS \\
\hline Albumin index & $1.24 \pm 0.05$ & $1.29 \pm 0.10$ & $1.26 \pm 0.03$ & $1.32 \pm 0.05$ & $1.20 \pm 0.04$ & NS \\
\hline
\end{tabular}

${ }^{a, b, c}$ Mean values in a row with different letter superscripts are significantly $(\mathrm{P}<0.05)$ different. $*=(\mathrm{P}<0.05)$; NS= Not Significant.

Table 6: Cost implication of feeding homemade and commercial layers' diets to Shaver brown hens

\begin{tabular}{|c|c|c|c|c|c|c|}
\hline Parameters & $\begin{array}{l}\text { Commercial } \\
\text { diet A } \\
\text { (control) }\end{array}$ & Homemade diet B & Commercial diet $\mathrm{C}$ & Commercial diet $\mathrm{D}$ & Commercial diet $\mathrm{E}$ & Sig. \\
\hline $\begin{array}{l}\text { Dozens of eggs produced } \\
\text { per bird (dozen) }\end{array}$ & $5.72 \pm 0.60$ & $5.05 \pm 0.12$ & $6.01 \pm 0.18$ & $4.88 \pm 0.71$ & $4.54 \pm 0.53$ & NS \\
\hline Price per crate of egg ( & 650.00 & 650.00 & 650.00 & 650.00 & 650.00 & - \\
\hline Cost of $\mathrm{kg}$ of feed & 74.00 & 60.00 & 72.00 & 72.00 & 70.00 & - \\
\hline Total feed consumed $(\mathrm{kg})$ & $7.13 \pm 0.39^{\mathrm{a}}$ & $7.01 \pm 0.37^{\mathrm{a}}$ & $7.52 \pm 0.11^{\mathrm{a}}$ & $7.83 \pm 0.51^{\mathrm{a}}$ & $5.46 \pm 0.23^{\mathrm{b}}$ & $*$ \\
\hline Cost of feed consumed( $($ ) & $527.62 \pm 5.54^{\mathrm{a}}$ & $420.60 \pm 4.26^{\mathrm{b}}$ & $541.44 \pm 4.11^{\mathrm{a}}$ & $563.76 \pm 4.55^{\mathrm{a}}$ & $382.20 \pm 6.01^{\mathrm{b}}$ & $*$ \\
\hline Price of a dozen of egg ( & 260.40 & 260.40 & 260.40 & 260.40 & 260.40 & - \\
\hline $\begin{array}{l}\text { Revenue from dozens of egg } \\
\text { produced( })\end{array}$ & $1489.49 \pm 2.81$ & $1315.02 \pm 3.08$ & $1565.00 \pm 4.81$ & $1270.75 \pm 2.04$ & $1182.22 \pm 2.95$ & NS \\
\hline Gross profit ( & $961.87 \pm 2.28$ & $894.42 \pm 3.34$ & $1023.56 \pm 4.23$ & $706.99 \pm 2.08$ & $800.02 \pm 2.17$ & NS \\
\hline
\end{tabular}

\section{Cost Implication of Feeding Homemade and Commercial Layers' Diets to Shaver Brown Hens}

Table 6 shows the economic implication of feeding homemade and four commercial diets to Shaver brown hens. Although dozens of eggs produced per bird, revenue from dozens of eggs produced and gross profit were not significantly $(\mathrm{P}>0.05)$ affected by dietary treatments, there were significant $(\mathrm{P}<0.05)$ differences among treatments in total feed consumed and cost of feed consumed. Birds fed diet $\mathrm{E}$ had significantly $\mathrm{P}<0.05)$ lower total feed intake value than those fed diet B (Self-compounded), commercial diets A (reference diet), $\mathrm{C}$ and $\mathrm{D}$, which had similar total feed intake values $(\mathrm{P}>0.05)$. The values of cost of feed consumed by birds fed commercial diets A, C and D were similar and these were significantly $\mathrm{P}<0.05$ ) higher than the values recorded for birds that consumed diet B (self-compounded) and commercial diet E. Birds that were consumed diet $\mathrm{B}$ and commercial diet $\mathrm{E}$ had similar cost of feed consumed. Adebayo et al. (2002), and Umeh and Odo (2002) state that feed cost as well as the quality of the feeds are among the factors which dictate farmer's preference for commercial or self - compounded feeds. Many farmers therefore, change from one commercial feed to another in search of cheaper and better feeds while a good number have decided to produce own feeds. The implication is that farmers may likely go for diet B (self-compounded) and commercial diet $\mathrm{E}$ as these would help to reduce the cost of production. Considering the non-significant $(\mathrm{P}>0.05)$ differences observed among dietary treatments in hen day production percentage, body weight gain, final body weight and gross profit (Tables 3 and 6), it does seem that none of the five diets (selfcompounded diet (B), commercial diets A, C, D and E) used in feeding the Shaver brown hens in this study was superior to the other. The farmer may therefore use any of them to feed laying birds, since the farmer's interest is in the final returns after sales (Afolayan et al., 2009). 


\section{CONCLUSION}

It can be concluded that since none of the five diets used in feeding the Shaver brown hens was superior to the other, farmers may therefore use any of them to feed laying birds. It must be noted that, The nutrient compositions of feed ingredients can be ascertained through proximate analysis which is a system of approximating the nutritive value of a feedstuff without carrying out feed trials on animals. This should be adopted by the commercial poultry feed sellers. It is also very important to carry out feeding trials on animals, before making any recommendation to farmers.

\section{REFERENCES}

Abeke, F.O., Sekoni, A.A., Oni. O.O., Adeyinka I.A. and Nwagu, B.I. (2008). Response of Shika-Brown pullet chicks and layers to Home Made and commercial feeds in Zaria, Kaduna State, Nigeria. Agro-Science Journal of Tropical Agriculture, Food, Environment and Extension.Volume 7 Number 3, September 2008 pp. 223 - 228.

Adebayo A.A, Salami S.B, and Oloyinde L. (2002) The influence of selected socioeconomic variables on poultry farmers choice of commercial and self-compounded feeds in Lagos area of Nigeria. Nigeria Journal of Animal production 2002, 29 (2); pp. 226233

Adesehinwa, A.O.K, Ikani, E.I., and Dafwang, I. I. (1996). Feed production for small scale livestock farmers. NAERLS Extension Bulletin.

Afolayan, M., Dafwang I.I., and Omage, J.J. (2009). Performance of broilers fed on-farm versus commercial feeds. Nig. J. Anim. Prod. 2009, 36(1): pp. $41-51$.

Agaviezor, B.O., Ajayi, F.O., and Adebambo, O.A. (2008). Genetic interrelationship existing between body weight, egg weight and egg internal quality traits. Proceedings of the $13^{\text {th }}$ Annual conference of the Animal Sc. Association of Nig. (ASAN) Sept. $15-19$ 2008 ABU Zaria.Pp 56-58.

Agbagha, F. M., Ezema F.U. and Omeke, B.C.O. (2000) Studies of management effects on fertility purebreds and crossbred exotic guts in two breeding farms at Nsukka, Nigerian Journal Animal Production. Vol. 28 (l) pp 20-21.

Asaiyan, B. K. and Laseinde, B. A. O. (2005). Comparative Studies of the performance of broiler chickens fed different commercial diets. Proceedings of the 30th Annual Conference of the Nigerian Society of Animal Production, pp: 121-126.
Association of Official Analytical Chemists (AOAC). 2006. Official Methods of Analysis. $18^{\text {th }}$ Washington, DC: AOAC.

Atteh J.O. (2002). Principles and practice of livestock feed manufacturing, Adlek Printers 64, Sabo-line Ilorin, Nigeria.

Atteh, J. O. (2004). Theory and practise of poultry production. Adlek Printer, Ilorin, Nigeria.

Breinholt, K.A, Gowen, F.A and Nwosu C.C (1981).Influence of environmental and animal factors day and night grazing activity of imported holstein Freisian cows in the humid lowland tropics of Nigeria. Trop. Animal Produc. Vol 6: pp. 4-5.

Dodusola, I. O., (2010). Comparative evaluation of internal and external qualities of eggs from quail and guinea fowl. International Research Journal of Plant Science. Vol. 1(5), pp. 112-115.

Duncan, D. B. (1955) New Multiple Range Test. Biometrics 11: 1-42.

Idahor, K.O., Adua, M.M., and Usman, A. (2010). Comparative proximate analysis of some commercial broiler feeds available in Lafia, Nasarawa State. Proc. $35^{\text {th }}$ Conf. Nig. Soc. for Anim. Prod.14 - 17 March, 2010, Univ. of Ibadan, Nigeria, pp. 341 - 343.

Jabeen, S., Salim, M and Akhta, P. (2004). Feed conversion ratio on major carp Cirrhinuiuriga/a fingerlings fed cotton seed meal. fish meal and barley. Pak. Vet. J. 24(1) Retrieved 19/11/2008 from http//pvj.cornpk pdf-files-24_1/42-45.pdf.

Jurgens, M .H. (2002).Animal feeding and Nutrition. $9^{\text {th }}$ Ed. Kendall/Hunt Pub.Coy. Iowa, USA.

Kehinde, A.S, Babatunde,T.O.; Ayoola, O.A. and Temowo, O.O (2006). Effect of different levels of protein on the growth performance characteristics of broiler chicks. Proc. $31^{\text {st }}$ Ann. Conf Nig. Soc. for Anim. Prod. (NSAP), March $12^{\text {th }}-15^{\text {th }}$ Bayero University, Kano: 235-237

Lorgyer, M. I., Odoh, O. E., and Onuh S. O. (2007). Performance of broiler starter chicks fed onfarm formulated and commercial diets. Proceedings of $32^{\text {nd }}$ Annual Conference of Nigerian Society for animal production, Cal; March 18-21, 2007. pp: 478-480.

Macdonald, P; Edwards, R.A; Greenhalgh, J. F. D and Morgan, C. A. (2002). Animal Nutrition, $6^{\text {th }}$ Ed. Pearson Education (Singapore) Press Ltd.,Delhi.

Ofomata, G.E.K. (1975) Nigeria in Maps. Eastern States. Ethiope Publishing Co. Ltd. Benin.

Olayeni, T.B., Farinu, G.O., and Ojebiyi, O.O. (2007).Replacement value of biscuit waste on the performance and egg quality parameters of laying hens. Proc. of the $32^{\text {nd }}$ Annual Conferences of the Nigeria Society 
for Animal Production, Calabar, March 18 21, 2007.

Oluyemi, J. A. and Roberts, P. A. (2000) Poultry production in warm wet climates $2^{\text {nd }}$ ed. Spectrum Books Ltd, Ibadan, Nigeria.

Payne, W.J.A and Wilson, R. T. (1999).An introduction to animal husbandry in the Tropics (5th Edition). Blackwell Science Ltd.

Singh, R.A. (1990). Poultry production. Kalyani bub. New Delhi- Ludhiana.

SPSS (2003). Statistical Package for Social Sciences, Windows Version 8. SPSS Inc. USA.
Steel, R. G. D and Torrie, 3.H. (1980). Principles and procedures of statistics. McGraw-Hill Book Inc. New York

Umeh, G. N. and Odo B. I. (2002).Profitability of poultry production among School Leavers in Anambra Local Government Area (LGA) of Ananibra State, Nigeria. Nig. J. Anim. Prod., vol. 29, pp 76 - 80.

Williams, C. (1992). Some factors affecting albumin quality with particular reference to Haugh Unit Score. World Poultry Science Journal, vol 48: pp 5-16. 